\title{
A Critique of 1976 Local Government Reforms: Its History, Structure And Impact After Forty Years In operation In Nigeria
}

\author{
Eze Michael Onyedikachi \\ Department of International Law and Diplomacy, Babcock University; \\ Oyagiri, Buduka Isaac; School of Law and Security Studies, Babcock University.
}

\begin{abstract}
Local Government as a political subdivision/unit is closest to the people and intracts with the locals in diverse ways that impacts citizens to feel they have government who listens and does its biddings; The absence of which leaves majority of locals with impression that there in no government or at least, it had not worked to improve the lots of its people. The aim of this study was to give a critique of the 1976 Local Government reforms: its history and structure after forty years in operation in Nigeria and to see lessons learnt if any. The study which is historical and qualitative in nature involved the use of content analysis of secondary data such as books, journal articles, case law, published and unpublished materials/reports and internet sources related to the study. Based on the analysis, it was discovered that the 1976 Local Government reforms did not satisfy a large segment of the Nigerian society. Local Governments have not been able to extricate themselves from the apron string of state and federal governments in Nigeria. The structure of power that ensures' unitaryfederal system and political value of the political elite as shown in State and Federal governments interventions in the affairs of Local Government have gone a long way in diluting the innovations brought about by the entrenchment of Local Government as a tier of government.

Finally, the study concluded that the defects which warranted the 1976 reform and restructuring of Local Government were sufficient but noted sadly that they are far from being resolved although the revolutionary approach to the structure, functions, powers and staffing in the Local Government Councils laid the foundation of modern local government administration in Nigeria
\end{abstract}

\section{INTRODUCTION}

Local government is defined by the United Nations (1959) as a political subdivision of a nation which is constituted by law and has substantial control of local government affairs including the power to impose taxes. The governing body of such an entity is elected or otherwise locally selected.

In his own contribution to the definition of local government, Oyediran (1988:8) views the concept as: Government in which popular participation both in the choice of decision-makers and in the decision-making process is conducted by the local bodies, which while recognizing the supremacy of the central government, is able and willing to accept responsibility for its decisions.

According to the Federal Government Guidelines for Local Government Reform (1976), local government is: Government at local level, exercised through representative councils, established by law, to exercise specific powers within defined area. These powers should give the council substantial control over local affairs as well as the staff and institutional and financial services and to determine and implement projects so as to compliment the activities of the state and federal government in their areas and to ensure, through devolution of functions to these councils, the active participation of the people and their traditional institutions, that local initiative and response to local needs are maximized.

Also according to Akpan (1984:28) from the above definitions, one can conveniently say that the term "Local government" is a theoretical abstraction which refers to sovereignty. Implicit in this statement is the fact that local government bodies are created and derive their powers from the state or central government. Local government bodies have corporate legal entity (person) subject only to limitations provided in the law establishing it or as may be made by the State House of Assembly and can sue and be sued in its name, it could hold property and dispose same as the law permits, can source, borrow and internally generate money to meet its financial obligations.(section 37 of Company and Allied Matters Act 2004). Additionally and importantly too, representatives at the local council at all times are to be popularly elected in obedience to section 7 of the 1999 Constitution (as amended). See also judgment of Lagos High Court of 24th October 2015 in Onuguruwa V. A.g Lagos State \& Ors where the Court held the appointment of Local government caretaker committee by Lagos State Governor as illegal and ordered the Lagos State Independent Electoral Commission to conduct election into all Local government area councils within 30 days from the delivery of the judgment. 


\section{II.}

\section{LOCAL GOVERNMENT REFORM IN NIGERIA}

The history of local government system in Nigeria dates back to the colonial days. Although contact with Europeans dates back to the fifteenth century, it was not until 1861 before steps were taken to establish an administration by Britain. The colonial administration that was established was based on indirect rule. This requires that the administration should be carried out through traditional rulers and institutions. This led to the establishment of native authorities in their most rudimentary forms from the 1890s to the 1930s. The main function of the native authorities was to maintain law and order.

The first native authority ordinance recognized traditional rulers as native authorities. This was easily done in Northern Nigeria but there was a problem in identifying who those authorities were in Southern Nigeria. This necessitated the first reforms in the 1930s and the 1940s culminating in the establishment of chiefs-incouncil and chiefs-and-council in place of sole native authorities. The Chief-in-Council consist of chief and members of council. The chief presides at all meetings and acts in accordance with the majority of opinion in the council. But if he disagrees with the council, he would take whatever action he thought best and inform the Governor of the Region. Contrarily, in the Chief-and-Council, the chief has no power to act against the decision or advice of the council. Under this arrangement, people particularly representatives of missionaries and British trading interest were appointed into the native authorities. The process of appointment of nominated members by the colonial government meant that nationalists were not appointed to serve on the councils. This led to further agitation for reforms in the native authorities.

In the years 1950-55, the first largely elected local government council based on the British Whitehall model emerged in Lagos and the former Eastern and Western Regions. Traditional rulers constituted not more than 25 percent of most Councils in the then Western Region and Lagos. However, in Northern Nigeria, the changes were more gradual. The legal framework for local government at this period was provided by the Eastern Region Local Government Ordinance of 1950, the Western Region Local Government Law of 1952 and the 1954 Native Authority Law in Northern Nigeria. By this time, the councils were given a wider range of functions including primary education, health, police, and judiciary. This is in line with the implementation of the colonial government's ten-year plan of welfare and development (1946-1956). The councils also enjoyed a great measure of autonomy in financial, personnel and general administrative matters. It can therefore be said that the 1950s was the era of pupilage for councils in modern local government throughout Nigeria.

From 1960 to 1966, there was a decline in the prestige and responsibilities of local authorities. In the former Western Region, the Local Government (Amendment) Law 1960 abolished the powers of councils to levy education and general rates on the basis of need. In Lagos, there was a high rate of default in the payment of property rates including government institutions, which reduced the revenue of the local councils. The situation in Eastern Nigeria was similar to the West before the outbreak of the civil war in 1967. In Northern Nigeria, there were gradual changes in the structure of the councils with increasing numbers of elected or appointed non-traditional office holders becoming members of local authorities. The result was that the local authorities had a stable administration, which enabled them to assume responsibility, with some degree of success for more complex services like primary education.

Between 1969 and 1971, some state governments including Kano, Bauchi, Enugu, Rivers, etc introduced some changes in the structure of their councils. Before the reforms of 1976, local governments in Nigeria varied in names and in structures from the various regions of the country.

Omorogiuwa (1993) revealed that apart from inadequate fund, poor staffing and before 1966, excessive politicking, the state government's deliberate encroachment on functions of Local Government over the years made progress impossible for local government councils. Thus, before the introduction of the 1976 local government reforms the local government in Nigeria was quite deficient in structure, size, staffing and finance; a development which inhibited their effectiveness as agents of national integration and grass root development (Aworawo and Akpan, 2003).

\section{REASONS FOR 1976 LOCAL GOVERNMENT REFORM}

Brigadier Shehu Musa Ya'Adua who was the then Chief of Staff, Supreme Headquarters in his forward to the guidelines stated some reasons among others for the reform thus:

The defects of previous local government systems are too well known to deserve further elaboration here. Local Government has, over the years, suffered from the continuous playing down of their powers. The State Governments have continued to encroach upon what would normally have been the exclusive preserves of Local Government. Lack of adequate funds and appropriate institutions had continued to make Local Government ineffective and ineffectual. Moreover, the staffing arrangement to ensure a virile Local Government system had been inadequate. Excessive politicking had made even modest progress impossible. Consequently, there had been a divorce between the people and the government institutions at their most basic levels. (Guidelines Local Government Reform, 1976). 
His statement is indicative of the fact that the existing local government system in the country prior to the 1976 local government reforms had fundamental problems which the reforms were to address. It was perhaps, in recognition of these problems and the need for urgent redress that he had declared that it was necessary to stabilize and rationalize government at the local level through decentralization for some significant functions to local levels in order to harness local resources for rapid development.

Awofeso (2004) observed that what later became known as the 1976 Local government reforms had its root in the 1974 Public Service Review Commission (Udoji Commission) which included in its comprehensive report, some recommendations on local government reforms. He noted that aside from the recommendations which brought about the unified single-tier local government systems, other recommendations served as framework of ideas on which the guidelines of the Local Government reforms of 1976 were later based.

It is important here to re-state five of the platforms of the 1976 local Government reforms and they are; to institute an enduring viable Local Government Council System; the creation of a system that could serve as a catalyst for the development of the areas involved; to have a local government with a uniform structure through a one-tier system such that a local government would not be less than 150,000 people or more than 800,000 people, to insulate the exalted and respected position of traditional rulers from the vagaries of partisan politics; and finally as eloquently stated in the Local Government Reform Guidelines of 1976 was the need to guide against the situation where "The state governments have continued to encroach upon what would normally have been the exclusive preserve of the Local Government".

According to Enyi (2014), before the 1976 Local Government reforms, previous reformed Local Government Authorities "lacked not only independent revenue capacity, but also the executive and absorptive capacities". In other words, they were financially dependent on higher authorities. Lack of qualified staff both administrative and technical and the fact that the members of the reformed local government administrations continued to be nominated and therefore had no commitment and moral obligation to the people in the rural areas made a mockery of the reforms.

It must be concluded that the reformed local governments, however structured and operated, were run like decentralized units of State governments between 1968 and 1975. It is, therefore, obvious that when in 1976 the Military Government of General Murtala Mohammed and Obasanjo carried out its reform, it had its conviction about the inadequacies of the prevailing local government system and the necessity for a drastic change.

Having realized that there were many defects inherent in the then prevailing local government, the Federal Military Government made changes in the Nigeria local government system. Oyewo (1987) observed that as contained in the guidelines these proposals for reforms were intended to stimulate democratic selfgovernment and to encourage initiative and leadership potential. He noted that the Federal Military Government believed that was only through an effective local government system that the human and material resources could be mobilized for local development. Not only that such mobilization implies more intimate communication between the general public and the government and above all, these reforms were intended to entrust political responsibilities to the people.

Thus, realizing the need for reform, the then Federal Military Government in late 1975 began tentative discussion through the establishment of a small co-operative committee. The membership of the local councils was through election (either direct or indirect) the first of which was organized throughout the country in November of that year (1976). One of the most important features of the 1976 Reform consisted in its recognition of local government as a distinct level of government in the country with specified functions and sources of finance. All these later received recognition of the 1979 Constitution of the Federal Republic of Nigeria. Thus, for example the 1979 and 1999 Constitution both in Sections 7(5) conferred on the local governments two key functions as set out in the Fourth schedule. Such functions includes:

1. a. consideration and making recommendations to state economic planning or any similar body on the economic development of its area of the state;

b. collection of rates, radio and television licenses;

c. establishment and maintenance of commentaries, burial grounds and homes for destitute or infirm;

d. licensing of bicycles, trucks, (other mechanically propelled trucks), canoes, wheel barrows and cart;

e. establishment, maintenance and regulation of slaughter houses, slaughter slabs, markets, motor parks and public conveniences;

f. construction and maintenance of roads, streets, street lightings, drains and other public highways, parks, gardens, open spaces, or such public facilities as may be prescibed from time to time by the House of Assembly of a state;

g. naming of roads and streets and numbering of houses;

h. provision and maintenance of public conveniences, sewage and refuse disposal;

i. registration of all births, deaths and marriages;

j. assessment of privately owned houses or tenaments for the purpose of leving such rates as may be prescibed 
by the House of Assembly of a state; and

k. control and regulation of :-

i. out - door advertising and hoarding,

ii. movement and keeping of pets of all description;

iii. shops and kiosks,

iv, restaurants, bakeries and other places for sale of food to the public,

v. laundries, and licensing, regulation and control of the sale of liquor.

2. The functions of a local government council shall include participation of such council in the government of a state as respects the following matters-

a. the provision and maintenance of primary, adult and vocational education;

b. the development of agriculture and natural resources, other than exploitation of minerals;

c. the provision and maintenance of health services; and

d. such other functions as may be conferred on a local government by the House of Assembly of the state.

This paper is not the proper forum to state whether or not in law, a nebulous provision can be stretched and added to by the State House of Assembly, of course, a plain interpretation can afford one this view but this is not even our concern here but to stress that these functions are crucial in the overall development of any state in the federation and the Federal and State governments must encourage the local governments to effectively and active play their constitutional roles.

In a similar vein, the Constitution (1979) in section 149 (4) (5) (6) and (7) established secured sources of finance for the local governments in Nigeria and are materially the same provisions now housed under section 162 subsections (3)(4)(5)(6)(7) and (8) of the 1999 Constitution of the Federal Republic of Nigeria (as amended).

Omoroguiwa (1993) argues that in this connection, the Federal Military Government embarked on extensive consultation regarding the best system of local government suitable for Nigeria. He explained further that the various committees were discussed at the various levels in Enugu, Ibadan and Kaduna. There was also a national conference at Ibadan where the recommendations of the various committees from the various zones were discussed.

It is important to stress at this point that what distinguishes the 1976 local government reform from all previous reform exercises in Nigeria is its formal and unequivocal recognition of local government as constituting a distinct level of government with definite boundaries, clearly stated functions and provisions for ensuring adequate human and financial resources (Adamolekun 1979); (Gboyega 1987 and Adeola 2009). Thus, for the first time in the history of Nigerian Federation, attempt was made to create a place for local government as a third tier level of government with emphasis on the autonomy of the said institution.

The 1976 Local government reform brought uniformity into the structure and functions of local government throughout the country. It also brought uniformity in names. All councils were to be known as local councils. To be viable and perform effectively, each local government area is to have a population of 150,000 to 180,000 but no town should be split no mater its populations. Another major highlight of the reform was the fact that local councils would include elected representatives and traditional rulers. The elected members are to elect their chairman whose appointment has to be approved by the Governor.

The Emir or paramount traditional ruler is to be a ceremonial president of the local government council in his domain. Ayo (1995) noted that one issue that was left to local government's direction was the method of electing council members to the local government. There was also the establishment of the Local Government Service Commission which was responsible for the appointment, condition of service, promotion, discipline, transfer and retirement of middle level and senior local government officials as from grade level 07 and above. In addition, the function of the Ministry of Local Government is spelt out and includes community development.

The 1976 local government reform also made provision for supervisory councilors. They were put in charge of the four prescribed areas which include finance, education, health and work. The 1976 local government reform was a clear departure from previous local government in Nigeria in the sense that it established a multi-purpose single tier local government with complete and self-contained budgets so that the entire systems of local government can be identified, cost and coordinated.

There was also uniformity in the functions, structure, staffing, administration, relationship with traditional rulers, inter-ministerial relations and the basis for sharing federal and state grants to local government councils and above all the local government was recognized as a third level of governmental activity.

\section{CRITIQUE OF THE 1976 LOCAL GOVERNMENT REFORMS} AND ITS STRUCTURE

Critics argued that there could not be rigid demarcation of local government area with references to geographical contiguity, population density, resources available and functions.

Aworawo and Akpan (2003) claimed that in spite of the lofty ideals generated by the 1976 Local Government 
reforms, it did not satisfy a large segment of the Nigerian society. According to them, in some states there were conflicts between the legislature and the executives because of disagreements over the number of local governments to be created. Within a period of two years, the number of local government practically jumped from 301 in 1979 to over 700 local governments. A committee which was set up and led by Alhaji Dasuki to look at the deplorable condition of local government in Nigeria on $28^{\text {th }}$ May 1984 by General Buhari's administration came up with a report that the 1976 reforms had more operational problems rather than structural problems. He also stressed the negative roles of the state governments in the administration of local government in the second republic. (Aworawo and Akpan 2003).

All efforts in the 1976 reform to recognize Local Government as a tier of government have been futile; Local Government is still an appendage of state and federal governments. Despite the constitutional elasticity provided for Local Government system beginning with the 1979 constitution and subsequent ones that defined functions and sources of funding of the system, local governments have not been able to extricate themselves from the apron string of State and Federal governments in Nigeria (Osaghae, 2006). The higher levels of government interfere in their operations in ways that undermine their autonomy.

The financial paucity in Local Government could be blamed on what Suberu (2004:16) referred as the cost of distributive federalism in his words, for a federal system that is dominated by the redistribution of central collected revenue. Most Local Governments in Nigeria are contented with the federal or state financial allocation to them, thereby becoming a mere distribution outlet for federal and state generated revenue. The architect of 1976 Local Government reform bewailed that Local Government have produced exactly the opposite of their original objectives. Instead of bringing development closer to the people in the grass root they bent on producing absentee chairmen who are seen only at the council headquarters when the monthly "Abuja Allocation" arrives and vamoose with their standby Jeeps and Mobile police escorts after super-intending over the sharing of the national cake among the relevant stakeholders.

Most governors have exploited the constitutional provision for the establishment of joint state and local government account to control local Government funds; they hijack the nomination and subsequent election for their acolytes as council chairmen. Aspirants who emerge victorious after rigorous process paid allegiance and political dues to the governor by accepting whatever deductions they make from the joint state- local government account. Nigeria lacks equity and fairness in sharing revenue as epitomized by the incessant manipulation of revenue allocation criteria and tax policies by the political class. There is the growing practice among the state governments to divert local government funds through state-local government joint account. This is possible because local government allocations from the federation account are disbursed through the state governments. Most State governments have taken this advantage to divert part of the allocation to otiose projects thereby robbing the local governments of the capacity to perform their functions and live up to the expectations of the people. In 2010, Benue State House of Assembly suspended 12 Council Chairmen in the State and directed that the Chairmen should refund 150 million naira financial misdeeds associated with the excess crude funds received by Local Governments in the State (National Mail, Issue 12). The situation is not different in Rivers State where elected council chairmen and councilors were sacked at the will and caprices of the governor using the Rivers State House of Assembly. (www.nationalnetworkonline.com $>$ Sack...; www.naij.com HYPERLINK "http://www.naij.com HYPERLINK "http://www.naij.com>latest/"> HYPERLINK "http://www.naij.com>latest/"latest/" HYPERLINK "http://www.naij.com>latest/"> HYPERLINK "http://www.naij.com HYPERLINK "http://www.naij.com>latest/"> HYPERLINK "http://www.naij.com>latest/"latest/" HYPERLINK "http://www.naij.com>latest/"Latest nigeriatrends.com>amaechi-recalls-sack...; $\quad$ www.pmnewsnigeria.com HYPERLINK "http://www.pmnewsnigeria.com HYPERLINK "http://www.pmnewsnigeria.com>2013/04/23)Also"> HYPERLINK "http://www.pmnewsnigeria.com>2013/04/23)Also"2013/04/23)Also" HYPERLINK "http://www.pmnewsnigeria.com>2013/04/23)Also"> HYPERLINK "http://www.pmnewsnigeria.com HYPERLINK "http://www.pmnewsnigeria.com>2013/04/23)Also"> HYPERLINK "http://www.pmnewsnigeria.com>2013/04/23)Also"2013/04/23)Also" HYPERLINK "http://www.pmnewsnigeria.com>2013/04/23)Also"2013/04/23)Also in Enugu state, former governor Chimaroke Nnamani was arrested and prosecuted on the allegation of diverting Local Governments' funds by the Economic and Financial Crime Commissions (http:www.articlesbase.com), it is surprising that 31 former governors tampered with local government funds (Ukiwo, 2006).

The structure of power that ensures' unitary-federal system and political value of the political elite as shown in State and Federal governments interventions in the affairs of Local Government have gone a long way in diluting the innovations brought about by the entrenchment of Local Government as a tier of government. The 1999 constitution by its provisions in Section 7 and 8 recognize the Local Government as a third tier of government and also guarantee it, but gives the State the power to lord over the Local Government. Section 7 reads jointly with Section 8 provides that there shall be:

The system of Local Government by democratically elected Councils (which) is by this Constitution guaranteed 
and accordingly, the government of every State shall, subject to Section 8 of this Constitution...ensure their existence under a law which provides for the establishment; structure, composition, finance and functions of such Councils.

The implication of these provisions is that Local Government has been structured in such a way that it cannot exercise the functions assigned to it in section 1 schedule 4 of the Constitution until the State House of Assembly had passed a law.

Also, the 1999 constitution empowers the State to determine and create new Local Government Areas. Section 8 (13) provides modalities for the creation of new Local Government Areas and vests the power to do so on various State Houses of Assembly. Section 8 (6) of the constitution however empowers the members of the National Assembly to ratify them. This provision also brought about the tussle for the control of local government between the State and Federal government.

Many States (for example, Kogi, Lagos, Niger, and Oyo) created more Local Government Areas in line with the modalities stipulated in the Constitution, but the Federal Government refused to recognize them. A State like Lagos, decided to recognize and fund the new Local Government Areas it created. This generated a rift between Lagos State and the Federal Government in which the Federal Government stopped the statutory allocations for the State.

Nwabueze (1983) and Ugwu (2003), also observed that the Constitutional power to establish Local Government and define its structure, composition and functions belong to the State Government. If this is the case, then, the Local Government is a mere State agency or a creation of State Government. It is therefore erroneous to see it as an independent third tier of government which can structure itself by itself. The same Fourth Schedule of the Constitution also provides for "the functions of the Local Government Council to also include participation of such Council in government of State as in respect of the following matters like education, agricultural materials and resources, healthcare and other function assigned to it by the State House of Assembly.

Another area of concern is the issue of elections in the Local Government Council and their tenure. $2^{\text {nd }}$ section 7 (6) of the 1999 Constitution provides for a democratically elected Local Government Councils. While the Constitution provides for four year tenure for Federal and State political office holders, it was silent on the tenure of the Local Government political office holders. This according to Nwabueze (1983) is structural imbalance between the tiers of government in Nigeria.

\section{CONCLUSION}

The 1976 Local Government Reforms in Nigeria have been variously described as a watershed, an ingenious reformation, a catalyst for sustainable and meaningful local governance, and a radical departure from Local Government administration of convenience to a Local Government system of content (Ugwu, 2001). It is important to stress that the 1976 local government reform marked the beginning of the modern local government administration in Nigeria. The reform according to Okoli (2005) formally and legally recognized local government as the third tier of government in Nigeria. The reform made deliberate efforts to set up a local government structure aimed at bringing government nearer to the people. As third tier of government, the local government gets statutory grants from Federal Government, and is expected to serve as agent of grass root development especially in rural areas.

In conclusion, there were defects which brought about the review of the 1976 Local Government Reform and its structure which were later amended. However, the powerful message of the 1976 reforms could be felt in its revolutionary approach to the structure, functions, powers and staffing in the local government councils.

\section{REFERENCES}

[1] Adamolekun, L. (1979), "The idea of Local Government as a third tier level of Government" In Adamolekun, L and Lowland (eds), The New Local Government system in Nigeria. Ibadan: Heinemann Educational Books.

[2] Adeola, G.L. (2009), From native Authority to Local Government: Is there a system of Local Government in Nigeria? In Sylvester odion Akhaine (ed) Local Government Administration in Nigeria: Old and New Visions. Lagos: CENCOD pp-2-21

[3] Adewunmi, J.B. (1992), Local Government in Nigeria: The changing Scene. Volume II, Benin City. Ethiope Publishing Corporation

a. Africa

[4] Akpan, P.C. (1984). Modern Local Government Administration in Nigeria: Kaduna, Baraka

[5] Aluko, J.O (2006) Corruption in Local Government System in Nigeria; Book Builder Edition

[6] Awofeso, O. (2004), Issues in Local Government Administration in Nigeria Lagos: Lis Johnson

[7] Aworawo, D. and Akpan E. (2003) "Local Government Administration" in Akinjide, O et, al (eds) Issues 
in Nigeria Government and Politics. Ibadan: Rex Charles Publications PP 218-243

[8] Ayo, S.B. (2003) "The Evolution of the Nigerian Local Government System, in Awotokun A.M (ed) New Trends in Nigeria Local government "Ile-Ife: O.A.U Press Ltd

[9] Company and Allied Matters Act, Cap. C20 Laws of the Federation of Nigeria, 2004

[10] Enyi, J.E (2014) Native Authorities and Local Government Reforms in Nigeria since 1914; Makurdi. University Press.

[11] Federal Republic of Nigeria (1976), Guidelines for the reform of Local Government in Nigeria Kaduna: Government Printers.

[12] Gbooyega, A (1987), Political Values and Local Government in Nigeria, Lagos; Matthouse Press.

[13] Okoli, M.U (2005), Local Government Administration System: An introductory and Comparative Approach. Onitsha: Abbot Books Ltd.

[14] Omorogiuwa, (1993), "Local Government in Nigeria” in Ola R.O.F (eds)

[15] Osaghae, E. (2006): Nigeria since Independence: Crippled Giant. Ibadan: John Archers Publishers Ltd.

[16] Oyediran, O. (1988). Essays on Local Government Administration in Nigeria: Lagos, Project

[17] Oyewo, A.T (1987), Nigeria Local Government Administration Politics and Management. Ibadan: Jator Publishing Company

a. Press.

b. Publishers

c. Resources Publisher

[18] Suberu, .R (2004): Attractions of Multi-Ethnic Federalism: The Nigerian experience. Ibadan: University of Ibadan Press

[19] The 1979 Constitution of the Federal Republic of Nigeria

[20] Ugwu, S.C. (2001). Issue in Local Government and Urban Administration in Nigeria. Enugu: Academic Publishing Company

[21] United Nations (1959). Public Administration: Aspect of Community Development New York.

[22] (www.nationalnetworkonline.com> "http://www.naij.comHYPERLINK

$$
\text { Sack...; }
$$
www.naij.com HYPERLINK "http://www.naij.com>latest/"latest/"HYPERLINK "http://www.naij.comHYPERLINK "http://www.naij.com>latest/"> HYPERLINK "http://www.naij.com>latest/"latest/"HYPERLINK "http://www.naij.com>latest/"Latest

[23] 1999 Constitution of the Federal Republic of Nigeria (as amended)

[24] nigeriatrends.com>amaechi-recalls-sack...;www.pmnewsnigeria.com

HYPERLINK "http://www.pmnewsnigeria.comHYPERLINK

"http://www.pmnewsnigeria.com>2013/04/23)Also">HYPERLINK

"http://www.pmnewsnigeria.com>2013/04/23)Also"2013/04/23)"HYPERLINK

"http://www.pmnewsnigeria.com>2013/04/23)Also">

"http://www.pmnewsnigeria.comHYPERLINK

"http://www.pmnewsnigeria.com>2013/04/23)Also">HYPERLINK

"http://www.pmnewsnigeria.com>2013/04/23)Also"2013/04/23)Also"HYPERLINK

"http://www.pmnewsnigeria.com>2013/04/23)Also"2013/04/23)Also (http:www.articlesbase.com), 